\title{
Prognostic implications of chromosomal findings in acute lymphoblastic leukaemia at diagnosis
}

\section{Summary and conclusions}

Chromosomes were studied on diagnostic bone-marrow samples from 39 children with acute lymphoblastic leukaemia (ALL). The patients were classified, according to the chromosomal characteristics of the major proportion of their leukaemic cells, into five categories: hyperdiploid, pseudodiploid, diploid, hypodiploid, and mixed. Patients in the hyperdiploid category had significantly longer first remissions than those in all other categories, and those in the pseudodiploid category had the shortest. Neither the absence of any normal cells nor the presence of detectable clones appeared to be an adverse feature.

We suggest that the proportion of hyperdiploid cells, determined by conventional chromosomal staining techniques, may be used as an additional prognostic feature in childhood ALL.

\section{Introduction}

No firm conclusion has yet been reached about the importance of chromosomal abnormalities in leukaemic cells in acute lymphoblastic leukaemia (ALL) in childhood. About half the children with ALL exhibit chromosome abnormalities in some of their bone-marrow cells at diagnosis, the commonest abnormality being hyperdiploidy. Most workers have concluded that the presence or absence of chromosome abnormality has no relevance for the course or prognosis of the disease. ${ }^{1-8}$ The success of the banding technique has been limited by the partial or total failure to produce bands on the fuzzy, ill-defined chromosomes characteristic of lymphoblastic leukaemia. At present the importance of the non-random changes at diagnosis reported in one study of banded chromosomes in $\mathrm{ALL}^{9}$ cannot be defined. We present evidence that the classification of children with ALL into categories according to the chromosomal characteristics of most of their leukaemic cells at diagnosis may have prognostic significance.

\section{Patients and methods}

The 39 children studied were aged between 4 months and 15 years and were diagnosed as having ALL at the Great Ormond Street and Royal Marsden hospitals between June 1971 and April 1975. They were examined at diagnosis as part of a serial study to determine chromosomal features during active disease and in remission, but we

\footnotetext{
Department of Cytogenetics and Immunogenetics, Institute of Cancer Research and the Royal Marsden Hospital, London SW3 6JJ

LORNA M SECKER-WALKER, PHD, lecturer

SYLVIA D LAWLER, MD, FRCPATH, consultant cytogeneticist
}

Department of Haematology, Institute of Child Health and the Hospital for Sick Children, Great Ormond Street, London WC1 3JH

R M HARDISTY, FRCP, FRCPATH, professor of haematology report here only the diagnostic chromosome findings. The patients were followed up until 30 June 1978.

Direct preparations for cytogenetic studies were made from a portion of the aspirate used for haematological diagnosis. The constitutional karyotype of the patients was determined from phytohaemagglutinin-stimulated lymphocytes. All chromosome preparations were stained by a Giemsa banding technique. ${ }^{6}$ Between three and 60 bone-marrow cells from each patient were analysed. The limited success of the banding technique at diagnosis led us to classify the patients by the chromosomal characteristics of most of the cells. These included the following categories: hyperdiploid (more than 46 chromosomes), pseudodiploid (46 chromosomes with rearrangements), diploid (normal 46), and hypodiploid (less than 46 with rearrangements). Patients with equal numbers of normal and abnormal cells were classified by the nature of the abnormal cells. When no chromosomal cell type was dominant the category "mixed" was applied. A clone was defined when two or more abnormal cells had the same additional chromosomes or rearrangements. Samples with under 10 analysable cells were considered to be inadequate for the detection of clones. The patients were treated with combination chemotherapynamely, UKALL I (five patients), UKALL II (16), and other similar regimens (18). ${ }^{10}$ All received cranial or craniospinal irradiation, either therapeutically or prophylactically.

\section{Results}

The table gives details of the patients in each chromosomal category.

Classification of 39 patients with acute lymphoblastic leukaemia by chromosomal category

\begin{tabular}{|c|c|c|c|c|c|c|}
\hline \multirow{2}{*}{$\begin{array}{l}\text { Chromosomal } \\
\text { category }\end{array}$} & \multirow{2}{*}{$\begin{array}{l}\text { Total } \\
\text { No of } \\
\text { cases }\end{array}$} & \multicolumn{2}{|c|}{ Sex } & \multirow[t]{2}{*}{ Age range } & \multirow{2}{*}{$\begin{array}{l}\text { No of } \\
\text { patients with } \\
\text { white cell } \\
\text { count } \\
>20 \times 10^{\circ} / 1\end{array}$} & \multirow{2}{*}{$\begin{array}{c}\text { No of } \\
\text { patients with } \\
\text { abnormal } \\
\text { clone (No } \\
\text { with clone/ } \\
\text { No with } \\
\text { adequate } \\
\text { sample) }\end{array}$} \\
\hline & & $M$ & $\mathbf{F}$ & & & \\
\hline $\begin{array}{l}\text { Hypodiploid } \\
\text { Pseudodiploid } \\
\text { Diploid } \\
\text { Mixed } \\
\text { Hyperdiploid }\end{array}$ & $\begin{array}{r}4 \\
6 \\
12 \\
2 \\
15\end{array}$ & $\begin{array}{l}1 \\
5 \\
7 \\
1 \\
8\end{array}$ & $\begin{array}{l}3 \\
1 \\
5 \\
1 \\
7\end{array}$ & $\begin{array}{l}4 \text { mths- } 8 \text { yrs } \\
22 \text { mths-15 yrs } \\
2-15 \text { yrs } \\
2-7 \text { yrs } \\
11 \text { mths-11 yrs }\end{array}$ & $\begin{array}{l}2 \\
4 \\
4 \\
1 \\
5\end{array}$ & $\begin{array}{c}4 / 4 \\
5 / 6 \\
2 / 9 \\
1 / 1 \\
10 / 10\end{array}$ \\
\hline
\end{tabular}

Ten of the 12 patients in the diploid category had minor populations of bone-marrow cells with abnormal chromosomes, which in two cases were clonal. The 27 patients in the other categories had a considerable range of abnormalities about the modal number, with at least some normal cells being present in 21 patients. Constitutional chromosome abnormalities were detected in two of the patients: one (and his father) had an unusual Y chromosome from which the entire banded portion of the long arm was missing; the other was constitutionally $47 \mathrm{XXY}$, though no phenotypic features of Klinefelter's syndrome were apparent at the age of 6 when ALL was diagnosed. In these two cases chromosomal classification was made on the additional abnormalities found in the bone marrow.

Complete remission was achieved within six weeks in all but one patient, in whom good partial remission was achieved after eight weeks. Nineteen patients were still alive 3.5-6.5 years after diagnosis, 16 of them in first remission. One patient died of chickenpox during his first remission, more than five years after diagnosis; another ${ }^{11}$ developed acute myeloid leukaemia and is regarded here as having relapsed.

The proportions of patients in first remission and of survivors in each chromosomal category were non-random (log rank test of Peto et $\left.a l^{12}\right)$. The figure shows that the proportion of patients in 


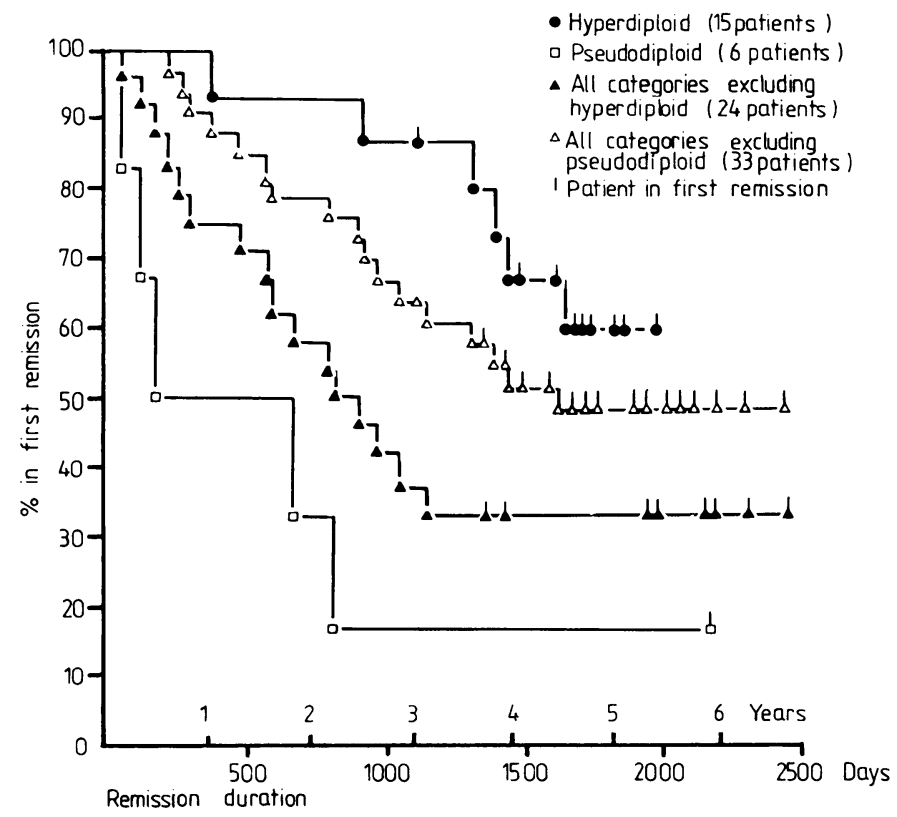

Durations of first remission according to chromosomal category.

first remission in the hyperdiploid category was consistently higher, and that of those in the pseudodiploid category consistently lower, than that of the rest of the patients combined $(\mathbf{P}<0.01$ at four years for each comparison).

There was no difference in either remission duration or survival between the patients in the diploid category and the rest, nor was the presence or absence of detectable clones important. Out of six patients who had only chromosomally abnormal cells at diagnosis, one relapsed after four years and the others remained in first remission for longer than this.

Since sex and white cell counts affect prognosis, these factors were examined for associations with the hyperdiploid and pseudodiploid categories. Although no significant differences were observed, five of the six patients in the pseudodiploid category were boys, of whom four had high white cell counts and two mediastinal disease. The leukaemic cells of one of the boys with mediastinal disease failed to form $\mathrm{E}$ rosettes or react with anti-ALL serum, and he would therefore be classified as having null-cell ALL by the criteria of Chessells et $\mathrm{al}^{13}$; the other patient, diagnosed in 1971 , was not tested in this way.

\section{Discussion}

The nature and proportion of the chromosomal changes seen in ALL at diagnosis were similar to those described. ${ }^{1-8}$ Like other workers we found no difference in remission duration or survival between patients with normal and abnormal bonemarrow chromosomes whether or not clonal abnormalities were detected. When our patients were classified according to the most common chromosomal characteristics of the cells, however, those in the hyperdiploid category had a longer duration of first remission than patients in all other categories. This is a new observation. The decreased remission durations found in patients in the pseudodiploid category have not been reported before, but, interestingly, none of the long-term survivors studied by Whang-Peng et $a l^{8}$ had been classified as pseudodiploid at diagnosis. The relatively poor outcome for this category in our series might have been due to an association with mediastinal disease: the only two patients with this presenting feature were both in the pseudodiploid category.

Our findings suggest that the chromosomal category at diagnosis, which is found by a simple technique that determines the proportion of hyperdiploid cells, may contribute with other known factors to prognostic assessment in ALL.

The relative importance of genetic and environmental factors in leukaemogenesis in man is still uncertain. Differences in chromosomal patterns found in ALL may reflect differences in aetiological agents, which has been discussed in relation to acute myeloid leukaemia by Rowley. ${ }^{14}$ On the other hand, the chromosomal findings may be a reflection of genetic response. The part played by genetic factors in leukaemia has been suspected for many years. ${ }^{15}$ Patients whose cellular response to the leukaemic agents takes the form of non-disjunction may be those whose genetic constitution favours response to longterm antileukaemic treatment, leading to eradication of the leukaemia.

We think that we have devised a way of obtaining cytogenetic data relevant to the clinician from material that is difficult to assess, the problems of obtaining good banded metaphases in leukaemic cells being well recognised. Such cytogenetic investigations must obviously be carried out before treatment starts. Clearly a larger study is desirable to substantiate the claims made on this small sample of patients. In future particular attention should be given to relating the cell surface markers to the chromosomal category of the major proportion of the leukaemic cells at diagnosis of patients with ALL.

We thank the consultants of the Royal Marsden Hospital for referring four patients, the medical art and photographic departments for the figure, and John Swansbury for technical help. The work was supported by the Leukaemia Research Fund.

Requests for reprints should be addressed to SDL or LMS-W, Royal Marsden Hospital, London SW3 6JJ.

\section{References}

${ }^{1}$ Reisman, L E, Mitani, M, and Zuelzer, W W, New England fournal of Medicine, 1964, 270, 591.

2 Kiossoglou, K A, Mitus, W J, and Dameshek, W, Blood, 1965, 26, 610.

3 Jensen, M K, Acta Medica Scandinavica, 1967, 182, 629.

4 Sandberg, A A, et al, Cancer, 1968, 22, 1268.

5 Whang-Peng, J, et al, Fournal of the National Cancer Institute, 1969, 42, 881.

${ }^{6}$ Lawler, S D, et al, Scandinavian fournal of Haematology, 1975, 15, 312

7 Fitzgerald, P H, and Hamer, J W, Fournal of the National Cancer Institute, $1976,56,459$.

8 Whang-Peng, J, et al, Medical and Pediatric Oncology, 1976, 2, 333.

9 Oshimura, M, Freeman, A I, and Sandberg, A A, Cancer, 1977, 40, 1161.

${ }^{10}$ MacLennan, I C M, Peto, J, and Kay, H E M, British fournal of Cancer, $1977,36,625$.

11 Secker-Walker, L M, and Sandler, R M, British fournal of Haematology, 1978, 38, 359.

12 Peto, R, et al, British fournal of Cancer, 1977, 35, 1.

13 Chessells, J M, et al, Lancet, 1977, 2, 1307.

14 Rowley, J D, Fournal of the National Cancer Institute, 1974, 52, 315

15 Till, M M, et al, British fournal of Haematology, 1975, 29, 575.

(Accepted 11 October 1978)

ONE HUNDRED YEARS AGO The Committee recently appointed by the Scientific Grants Committee of the British Medical Association "to organise an inquiry into the Causation, Pathology, and Treatment of Rabies and Hydrophobia," consisting of Mr Callender, FRS, Dr Burdon Sanderson, FRS, Dr T Lauder Brunton, FRS, Mr Ernest Hart, and Dr Gowers, desire to announce that they will feel favoured if any medical gentleman having under his care a case of hydrophobia will kindly communicate with them. In any cases of hydrophobia or of rabies in which a post mortem examination is made, they will be glad to receive for investigation the following parts namely, the spinal cord, medulla oblongata and pons Varolii, a small piece of the cerebellum, corpus striatum, convolutions of the middle third of the brain, one of the salivary glands, the nerves leading to the part bitten, portion of the liver and of the kidneys, and the scar. These should be at once placed in a mixture of equal parts of spirit and water (or, if the organs be at all softened by commencing decomposition, in a mixture of three parts of spirit to two parts of water), and forwarded with as little delay as possible, together with a report of the post mortem appearances, to the Office of the British Medical Association, 36 Great Queen Street, London, WC. (British Medical fournal, 1878.) 